\title{
Hybrid Electrocatalytic Ozonation Treatment of Simulated High-Salinity Carbamazepine Wastewater with $\mathrm{Ni}_{0.2}-\mathrm{Ce}_{0.2} / \mathrm{OMC}$ Particle Electrodes
}

\author{
Meng Zhang, Han Wang, Jianguo Wu, Hui Wang* \\ College of Environmental Science and Engineering, Beijing Forestry University, Beijing 100083, PR \\ China \\ ${ }^{*}$ E-mail: wanghui@bjfu.edu.cn
}

doi: $10.20964 / 2020.06 .23$

Received: 8 January 2020 / Accepted: 27 Feruary 2020 / Published: 10 May 2020

\begin{abstract}
High-salinity pharmaceutical wastewater contains refractory contaminants that can be effectively treated by hybrid electrocatalytic ozonation $\left(3 \mathrm{D} / \mathrm{O}_{3}\right)$. The salt in the wastewater provides a natural electrolyte, thus avoiding secondary pollution caused by the addition of electrolytes. In this work, we studied highsalinity pharmaceutical wastewater with carbamazepine as the main pollutant. Degradation experiments showed that the $\mathrm{Ni}_{0.2}-\mathrm{Ce}_{0.2} / \mathrm{OMC} / g$ ranular activated carbon (GAC) particle electrodes was effective, $3 \mathrm{D} / \mathrm{O}_{3}$ in combination with $\mathrm{Ni}_{0.2}-\mathrm{Ce}_{0.2} / \mathrm{OMC} / \mathrm{GAC}$ removed carbamazepine effectively. The optimal conditions for the degradation of the simulated high-salinity wastewater containing $25 \mathrm{mg} \cdot \mathrm{L}^{-1}$ carbamazepine by the $3 \mathrm{D} / \mathrm{O}_{3}+\mathrm{Ni}_{0.2}-\mathrm{Ce}_{0.2} / \mathrm{OMC} / \mathrm{GAC}$ process were: $10 \mathrm{~mA}$ current, $\mathrm{pH}$ of 2 , and a 5 $\mathrm{g}: 150 \mathrm{~mL}$ ratio of particle electrode to solution. Under these conditions, the carbamazepine removal ratio was $99.7 \%$, and the mineralization rate of the simulated wastewater was $75.7 \%$. The removal of carbamazepine follows pseudo first-order reaction kinetics. The $\mathrm{Ni}_{0.2}-\mathrm{Ce}_{0.2} / \mathrm{OMC} / \mathrm{GAC}$ particle electrodes exhibit good stability, and the main active species in the $3 \mathrm{D} / \mathrm{O}_{3}+\mathrm{Ni}_{0.2}-\mathrm{Ce}_{0.2} / \mathrm{OMC} / \mathrm{GAC}$ process is $\cdot \mathrm{OH}$.
\end{abstract}

Keywords: $\mathrm{Ni}_{0.2}-\mathrm{Ce}_{0.2} / \mathrm{OMC} / \mathrm{GAC}$; hybrid electrocatalytic ozonation treatment; high-salinity pharmaceutical wastewater; carbamazepine; conditions optimization

\section{$\underline{\text { FULL TEXT }}$}

(C) 2020 The Authors. Published by ESG (www.electrochemsci.org). This article is an open access article distributed under the terms and conditions of the Creative Commons Attribution license (http://creativecommons.org/licenses/by/4.0/). 